\title{
IGNEOUS CHARNOCKITES IN THE SOUTHEASTERN TRANSITION ZONE BETWEEN THE SÃO FRANCISCO CRATON AND THE COSTEIRO MOBILE BELT, BRAZIL
}

\author{
HANNA JORDT-EVANGELISTA*
}

\begin{abstract}
RESUMO CHARNOQUITOS ÍGNEOS NA ZONA DE TRANSICÃ̃O ENTRE O CRÁTON DO SÃO FRANCISCO E O CINTURÃO MÓVEL COSTEIRO, BRASIL Rochas félsicas e máficas com ortopiroxênios são importantes componentes da zona de transição entre o Cráton do São Francisco, de idade arqueana, e o Cinturão Móvel Costeiro, do Neoproterozóico, no sudeste do Brasil. O Charnoquito Pedra Dourada é composto de rochas félsicas pertencentes às séries charnoquito-enderbito e granito-tonalito intrusivas em piribolitos gabróicos. Entre as rochas félsicas e máficas ocorrem, além dos contatos claramente intrusivos, também contatos transicionais, do tipo migmatítico. Os charnoquitos mostram texturas magmáticas reliquiares que contrastam com as metamórficas dos piribolitos. Cálculos termobarométricos baseados na composição química de minerais coexistentes sugerem temperaturas entre 605 e $716^{\circ} \mathrm{C}$ e uma pressão de $7.3 \mathrm{kbar}(\sim 27 \mathrm{~km}$ de profundidade) para a formacão do corpo de Pedra Dourada. Pelas paragêneses de alto grau destas rochas, estas temperaturas são excessivamente baixas, possivelmente devido a um reequilíbrio nas composições químicas dos minerais durante o subseqüente soerguimento e deformação. Os dados de campo complementados pelas características mineralógicas, texturais e químicas do Charnoquito Pedra Dourada sugerem uma origem por fusão parcial de crosta continental profunda sob as condições anidras da fácies granulito. O magma félsico cristalizou em rochas das séries charnoquítica e granítica. Os piribolitos máficos são provavelmente restitos.

Este estudo mostra que charnoquitos de origem ígnea podem ser muito mais comuns nos terrenos do embasamento no mundo do que se tem até então admitido.
\end{abstract}

Palavras chave: Charnoquito ígneo, Petrologia, Cráton do São Francisco, Cinturão Móvel Costeiro

\begin{abstract}
Orthopyroxene-bearing felsic and mafic rocks are important components of the transition zone between the Archean São Francisco Craton and the Late Proterozoic Costeiro Mobile Belt in southeastern Brazil. The Pedra Dourada Charnockite is a felsic rock of the charnockite-enderbite and the granite-tonalite series which intruded into mafic pyribolites of a gabbroic composition. Besides the clearly intrusive contacts between the felsic and the mafic rocks, transitional, migmatite-type contacts also occur. The charnockites have relict magmatic textures which contrast with the metamorphic textures of the pyribolites. Thermobarometric calculations based on several exchange thermometers and one barometer suggest temperatures between 605 and $716^{\circ} \mathrm{C}$ and a pressure of $7,3 \mathrm{kbar}(\sim 27 \mathrm{~km}$ depth) for the generation of the Pedra Dourada Charnockite. Considering the high grade paragêneses of these rocks, calculated temperatures are too low, possibly due to reequilibration of mineral chemical compositions during subsequent uplift and deformation.

Field evidence, supplemented by mineralogical, textural, and chemical data of the Pedra Dourada Charnockite suggests an origin by partial melting of deep continental crust under the dry conditions of granulite facies. The felsic magma crystallized as rocks of the Charnockite and the granite series. The mafic pyribolites are likely to be restites. This study shows that charnockitic rocks of igneous origin may be much more common in basement terranes around the world than has so far been assumed.
\end{abstract}

Keywords: Igneous Charnockite, Petrology, São Francisco Craton, Costeiro Mobile Belt,

INTRODUCTION Charnockites are important components of the lower continental crust in many Precambrian terranes. They were first described by Holland (1900) in Madras, southern India, as orthopyroxene-bearing granitic rocks. In that region they are associated with orthopyroxenebearing granodiorite, tonalite and gabbro. Holland called this association the Charnockite Series and stated it is plutonic. In the last two decades, there has been much discussion about charnockites in terms of either an igneous or metamorphic origin.

An igneous origin, as postulated by Holland (1900) for the rocks in India, is consistent with the massive, homogeneous, undeformed nature of some charnockites and, in a few cases, the existence of intrusive contacts, xenoliths and magmatic textures. A charnockitic magma could be generated in the mantle or in the crust (Newton 1992a). Mantle derived magmas are less probable as a source because they are not granitic liquids nor have the appropriate composition to yield large amounts of granitic liquids by fractionation (Wyliie et al 1976, Newton 1992a). Crustal partial melts are commonly felsic. The heat needed to produce crustal melts can be furnished by the intrusion of hot, mantle derived magmas (Wyliie et al. 1976) or by self-heating processes due to crustal thickening in zones of plate convergence (Newton 1992a, Ashwal et al. 1992). The crystallization of charnockitic magmas occurs under anhydrous conditions in the granulite facies. Magmatic differentiation can generate the different rock-types of the series.

A metamorphic origin is postulated for most charnockites around the world, including the classic examples in Southern India, based on typical metamorphic textures, lithologic banding, and intercalations of metasediments (Cooray 1969, de Waard 1969). Charnockitic rocks of metamorphic origin are generated through subsolidus mineral reactions under granulite facies conditions $\left(\mathrm{T}=700-950{ }^{\circ} \mathrm{C}, \mathrm{P}=5-11 \mathrm{kbar}, \mathrm{Bo}-\right.$ hlen 1991). One of the main charnockitization reactions is (Perchuk \& Gerya 1992):

$$
\text { biotite }+ \text { quartz }=\text { orthopyroxene }+\mathrm{K} \text {-feldspar }+\mathrm{HzO}
$$

Some authors advocate a metamorphic-metasomatic origin through charnockitizating fluids rich in $\mathrm{CO}_{2}$ and poor in $\mathrm{H}_{2} \mathrm{O}$ (Newton et al. 1980, Newton 1992b) which also may contain alkalies (Perchuk and Gerya, 1992). These fluids cause dehydration reactions and generate the typically anhydrous paragêneses of the charnockites.

The nomenclature of rocks of the Charnockite Series is not simple. For the quartz-feldspar-rich varieties of either magmatic or metamorphic origin, the terms charnockite (granitic 
composition), charnoenderbite (granodioritic compositon) and enderbite (tonalitic or quartz-dioritic composition) are widespread (Shelley 1993). More problematic is the nomenclature for the mafic rocks of gabbroic composition. Some terms used are basic charnockite (e.g. Cooray 1969), mafic granulite (e.g. Fiorentini et al 1990), basic granulite (e.g. Sen and Ray 1971), norite (Tobi 1971), pyribolite and pyriclasite (Scharbert 1963). The term norite should be avoided for non-magmatic types; instead, pyribolite (for pyroxene and amphibole-bearing types) or pyriclasite (for pyroxene-bearing types) are more appropriate.

Certainly, igneous and metamorphic charnockites exist. All are formed under granulite facies and low Pmo- Only careful field, petrographic and geochemical studies will enable the identification of the different charnockite types of many areas of the world.

In the area between the São Francisco craton, in Minas Gerais, Brazil, and the eastern fold belt (Fig.l), many metamorphic charnockitic and granulitic bodies have been mapped and studied (Jordt-Evangelista \& Miiller 1986, Schulz-Kuhnt et al. 1990, Herbert et al. 1991). Detailed field work has shown that a much larger areal distribution of different kinds of charnockites actually exist. The purpose of this paper is to demonstrate that field, petrographic and geochemical evidence from the Pedra Dourada Charnockite favours the formation of its felsic rocks by igneous crystallization and not by metamorphic subsolidus reactions as other granulites and charnockites of the same zone.

GEOLOGIC SETTING The São Francisco craton (Almeidal 977, Almeida et al. 1981, Mascarenhas et al. 1984) in

southeastern Brazil (Fig. 1) is an Archean crustal block bor- dered by Brasiliano age deformed belts, among which the eastern belt is called Costeiro Mobile Belt (Hasui \& Oliveira 1984).

Located in the southernmost São Francisco Craton is the Quadrilátero Ferrífero (Iron Quadrangle), an important metallogenetic province composed of a gneisse-migmatite basement, an Archean granite-greenstone association (the Rio das Velhas Supergroup) and a Proterozoic metasedimentary sequence hosting a thick, Lake Superior-type, banded iron formation (the Minas Supergroup).

The area between the cratonic Quadrilátero Ferrífero and the eastern belt is a transition zone that was studied by JordtEvangelista \& Miiller (1986), Schulz-Kuhnt et al (1990) and Herbert et al. (1991). It consists mainly of gneisses of increasing metamorphic grade toward the east, and granulites and banded charnockites with metamorphic textures. The charnockitic rocks become more abundant eastwards.

The Pedra Dourada Charnockite is located in the central part of the transition zone, $10 \mathrm{~km}$ east of Dom Silvério (Fig. 1 ), and consistes of charnockitic, granitic and gabbroic rocks outcroping in an area of about $50 \mathrm{~km}$. It is surrounded by banded biotite gneisses and by metasedimentary rocks of lower' amphibolite facies belonging to the Dom Silverio Group (Jordt Evangelista 1992), which is considered to mark the suture zone of the collision between two cratons (São Francisco and Congo cratons) at 2.1-2.0 Ga (Cunningham et al., in preparation).

FIELD RELATIONSHIPS The Pedra Dourada Charnockite is notable for a peculiar association of more abundant felsic granitoids (orthopyroxene-bearing charnockite-enderbite and garnet-biotite-bearing granite-tonalite) and less abun-

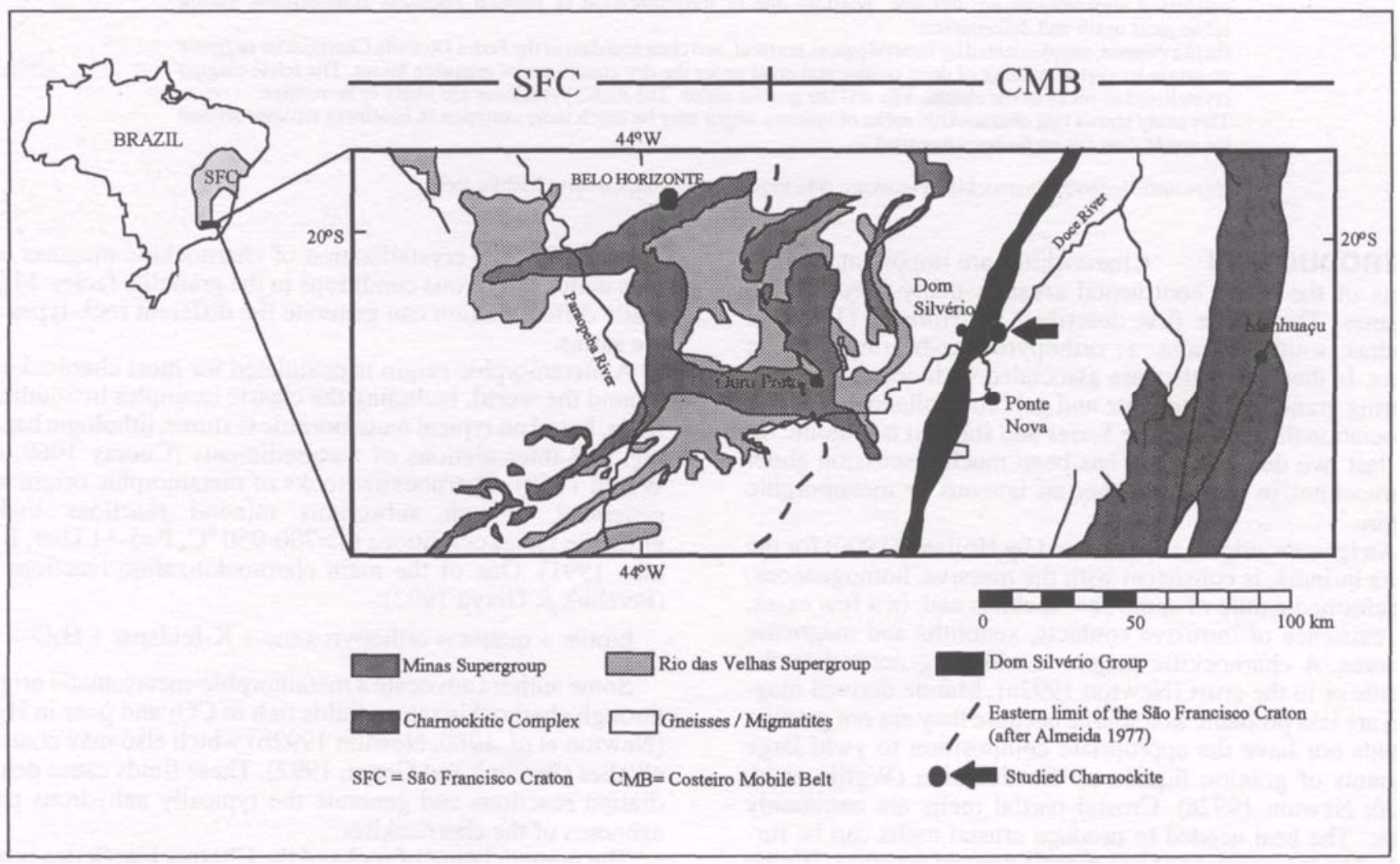

Figure 1 - Geological map of the southern São Francisco Craton and Costeiro Mobile Belt (modified after Schobbenhaus et al. 1984, Geologic Map of Brazil, 1:2.500.000, DNPM); location of the Pedra Dourada Charnockite.

Figura 1 - Mapa geológico da porção sul do Craton do São Francisco e do Cinturão Móvel Costeiro (modificado de Schobbenhaus et al. 1984, Mapa Geológico do Brasil. 1:2.500.000, DNPM); localização do Charnoquito Pedra Dourada. 


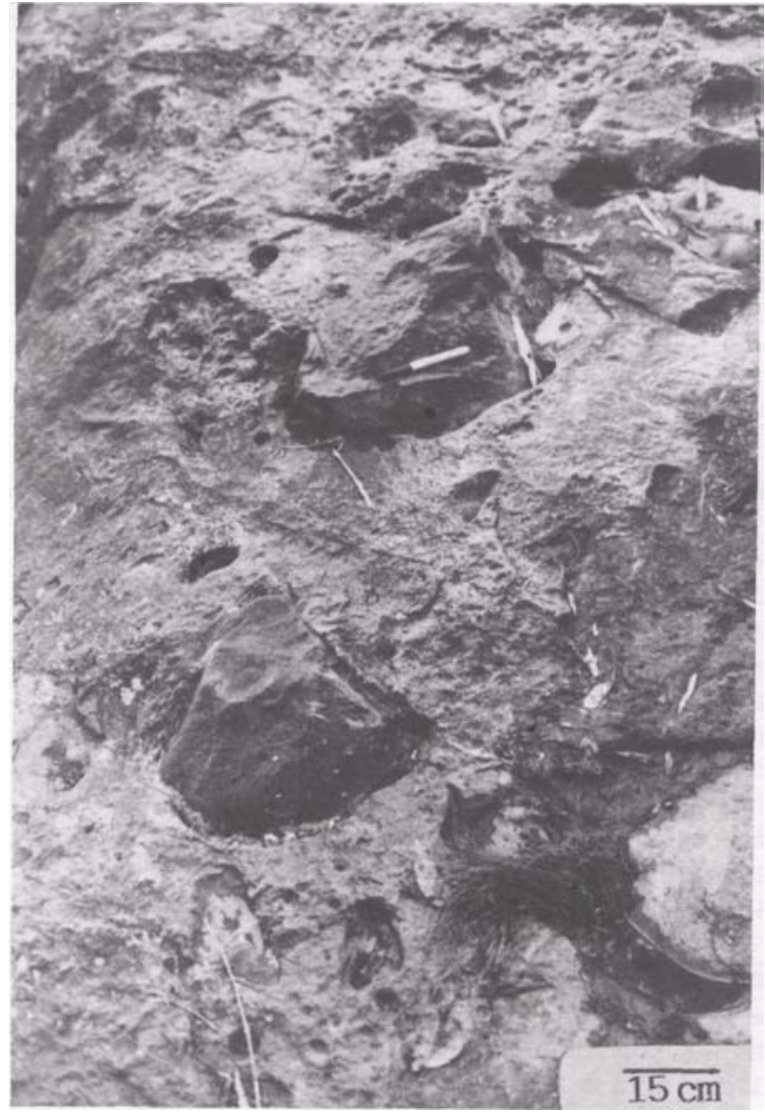

Figure 2 - Dark pyribolite xenoliths in charnockite. Figura 2 - Xenólitos escuros de piribolito em charnoquito.

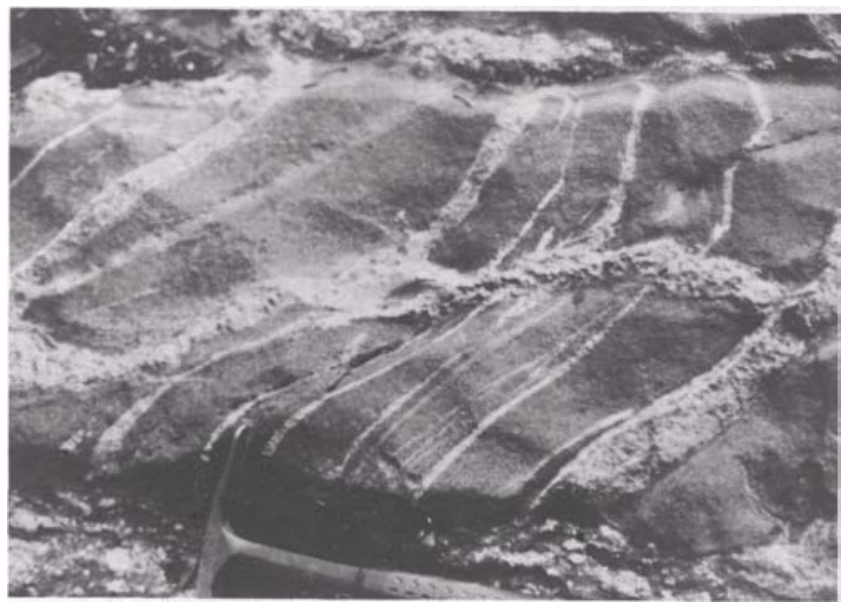

Figure 3 - Mafic pyribolite cut by fels ic charnockite. Figura 3 - Piribolito máfico cortado por charnoquito félsico.

dant mafic rocks (mainly pyribolite). The two types commonly occur in intimate spacial association.

The contacts between the mafic pyribolite and the felsic charnockitic-granitic rock are variable. Whenever the felsic rocks predominate volumetrically, they contain inclusions of centimetric to metric, rounded or lens-shaped masses of pyribolite (Fig. 2). When the mafic type predominates, the felsic rocks show intrusive, clearly cross-cutting contacts (Fig. 3)

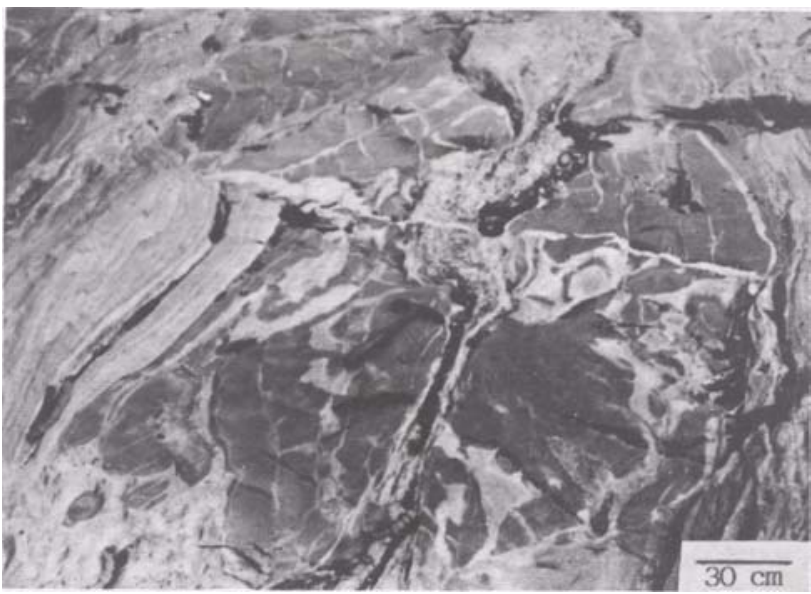

Figure 4 - Felsic charnockite and mafic pyribolite showing transitional contact.

Figura 4 - Charnoquito félsico e piribolito máfico mostrando contato transicional.

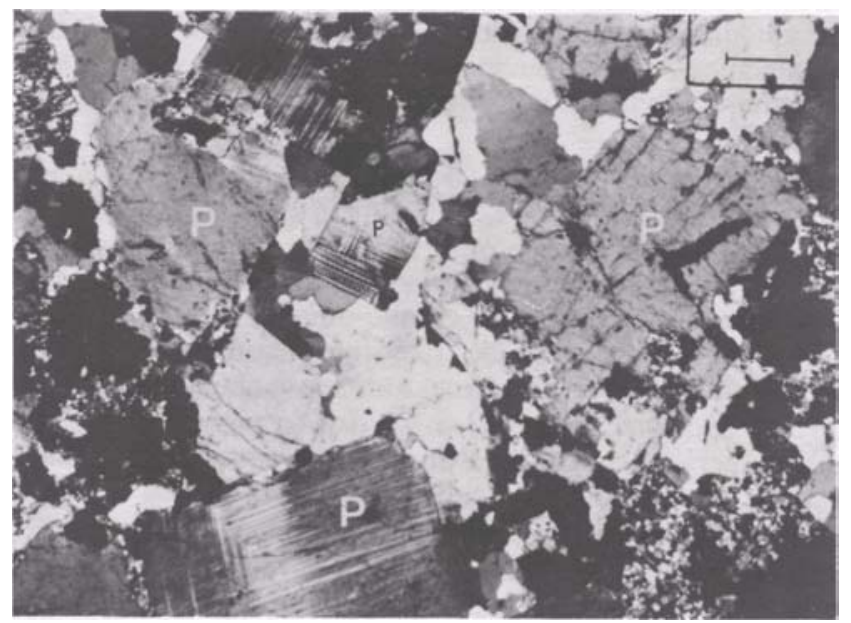

Figure 5 - Photomicrograph showing the magmatic texture of undeformed enderbite, with idiomorphic plagioclase $(P)$. Scale bar is $0.4 \mathrm{~mm}$.

Figura 5 - Fotomicrografia mostrando a textura magmática de enderbito indeformado, com plagioclásio idiomorfo $(\mathrm{P})$. Escala $=0,4 \mathrm{~mm}$.

and are, therefore, younger. Less commonly, the contacts tend to be gradational and migmatitic-like (Fig. 4).

Later penetrative solid state deformation and recrystallization of variable intensity locally caused mylonitic overprinting on the primary structures and textures.

The intrusive character of the felsic rocks is also corroborated by the presence of xenoliths of the regional gneisses. Both felsic and mafic types of the Pedra Dourada Charnockite are cut by younger, up to $10 \mathrm{~m}$ wide dykes of massive, finegrained diabase.

\section{PETROGRAPHY AND MINERAL CHEMISTRY}

Two major rock-types occur in the studied body. The mafic rocks are pyribolite and less common pyriclasite. The felsic rocks may be assigned to two rock series, namely the orthopyroxene-bearing charnockite-enderbite series, and the biotitebearing granite-tonalite series. The chemical composition of the most abundant minerals is in table 1. 
Mafic Rocks The mafic rocks are dark, greenish-gray pyribolites. A weakly defined mineralogical banding, with alternating plagioclase-quartz rich layers and typically gabbroic layers, is locally found. The texture is granoblastic. The main mineral is plagioclase (40 - $50 \mathrm{vol} \%)$. The andesine/ labradorite crystals (An44 - Anei) are well twinned after albiteand pericline-laws, and often show internal deformation. Brownish-green ferroan pargasitic hornblende (up to 50 vol\%) is usually crowded with tiny opaque needles. Hornblende occurs as both individual crystals, and as rims around pyroxenes. Orthopyroxene (up to $13 \mathrm{vol} \%$ ) is locally rimmed by hornblende or may show replacement by symplectitic intergrowths of rounded quartz + light bluish-green actinolite \pm colorless cummingtonite \pm fibrous biotite \pm carbonate. The Orthopyroxene has a composition Fs5iEn48Wooi. Clinopyroxene (Wo49En36Feis) reaches up to $15 \mathrm{vol} \%$, is always better preserved than the Orthopyroxene but also exhibits marginal replacement by symplectitic quartz + actinolitic amphibole. Garnet rims around the symplectite are also frequent.

Less abundant minerals are biotite with a $\mathrm{Fe} / \mathrm{Fe}+\mathrm{Mg}$-ratio of 0.47 , rounded apatite, zircon, and opaque minerals partially transformed into garnet. The secondary garnet Alm58Gros23Pyri3Speso4(And+Uv)o2 is much more calcic than the primary garnet found in the felsic rocks (see below). The amount of quartz, usually a constituent of the secondary symplectites, is small, but in the pyriclasites, which are richer in biotite, it is a major constituent reaching up to $20 \mathrm{vol} \%$.

Felsic Rocks The quartz-feldspar-rich rocks can be subdivided into two groups, according to their mafic minerals: (i) the Orthopyroxene \pm biotite \pm garnet-bearing varieties of the charnockite-enderbite series, and (ii) the biotite \pm garnet-bearing types of the granite-tonalite series. In most outcrops both types grade one into another. However, non-orthopyroxene-bearing rocks are more abundant.

Hand specimens vary from whitish to greenish-gray. A weak mineralogical banding due to different concentrations of mafic minerals occurs locally.

The most outstanding textural feature of the felsic rocks are euhedral to subhedral feldspar crystals surrounded by smaller quartz aggregates (Fig. 5). This hypidiomorphic texture is typical of a normal sequence of magmatic crystallization. Some samples have primary textures affected by later deformation.

Plagioclase (5 - $65 \mathrm{vol} \%$ ) is oligoclase-andesine (-Anso), and is usually antiperthitic. Twin lamellae are commonly bent and vanishing. Orthoclase $(0-57 \mathrm{vol} \%)$ has the compostion Or8sAbi2, and is euhedral to subhedral and often perthitic in charnockites and granites. In enderbites and tonalites it is either completely absent, or is intergranular or enclosed in plagioclase as antiperthite. Quartz $(20-47 \mathrm{vol} \%)$ is granoblastic and forms the matrix surrounding the larger euhedral feldspars. Orthopyroxene (EnsgFs42) is partially or totally converted into a fine grained quartz + actinolite \pm cummingtonite \pm biotite \pm carbonate intergrowth rimmed by garnet. It reaches up to $10 \mathrm{vol} \%$. Biotite (up to $20 \mathrm{vol} \%$ ) is reddish-brown. Larger, primary crystals, display a weak orientation and might have small, euhedral secondary garnet inclusions. In the least altered samples, biotite is richer in $\mathrm{Ti}$ and $\mathrm{Mg}\left(\mathrm{TiO}_{2}\right.$ up to 5.4 weight $\left.\%, \mathrm{Fe} / \mathrm{Fe}+\mathrm{Mg} \sim 0.36\right)$ than the biotite of pyribolites. Garnets (0-6 vol\%) are of two generations. Large, rounded or slightly elongate primary crystals of Alm66Pyr260rroso5Speso3 locally have spinel inclusions, while the secondary garnet rims Orthopyroxene or is enclosed in biotite.

Besides spinel, other accessory minerals are euhedral zircon, rounded apatite, metamictic allanite, opaque minerals and rounded monazite. Green spinel is found enclosed in garnet. It is a Cr-bearing gahnite-spinel-hercynite solid solution with a $\mathrm{Zn}: \mathrm{Mg}: \mathrm{Fe}$ ratio of $1: 1: 2$.

Minerals formed by diaphthoresis include rare chlorite, sericite and epidote.

THERMOBAROMETRY Temperatures were calculated by means of the biotite-garnet $\mathrm{Fe}-\mathrm{Mg}$ exchange thermometers of Ferry \& Spear (1978) and Perchuk \& Lavrent'eva (1983), of the garnet-orthopyroxene thermometers of Harley (1984) and Sen \& Battacharya (1984), and of the garnet-hornblende thermometer of Graham \& Powell (1984). The mineral chemistry is presented in Table 1 . The calculated temperatures (Table 2) vary between $604^{\circ} \mathrm{C}$ and $716^{\circ} \mathrm{C}$. Pressures of $7.3 \mathrm{kbar}$ were obtained by means of the garnet-orthopyroxene-plagioclase-quartz barometer of Perkins \& Chipera (1985). This pressure corresponds to a depth of approximately $27 \mathrm{~km}$.

The calculated temperatures are low for Orthopyroxene and spinel-bearing rocks. As discussed by Hodges \& Spear (1982), retrograde re-equilibration during uplift and cooling of metamorphic terranes may lead to significant underestimates of peak metamorphic conditions. Spear (1992) suggests that the interpretation of temperature and pressure conditions of granulite facies rocks is more accurate when based on the principles of the equilibrium of phases, that is, on the stability and compatibility of the mineral parageneses as indicated by textures. Spear (1992) states that it is much more difficult to destroy the evidence of precursor minerals or reaction textures than it is to alter the composition of the phases.

In the studied rocks there are many textural indications for the instability of minerals used in the exchange thermobarometers. There is also evidence for a strong deformation leading to local mylonitisation. The obtained relative low temperatures may therefore result from later re-equilibration of mineral compositions.

ROCK CHEMISTRY Chemical analyses of major and selected trace elements are presented in Table 3. Most of the quartz-feldspar-rich rocks plot in the granodiorite field of the Ab-An-Or diagram of O'Conner (1965) with a few in the granite, tonalite or trondjemite fields (Fig. 6).

In the alkalies - $\mathrm{FeO}_{\mathrm{t}}-\mathrm{MgO}$ diagram of Irvine \& Baragar (1971) the granitoids scatter about a calc-alkaline trend (Fig. 7). The mafic pyribolites however, plot in the tholeiitic field. Although the intermediate pyriclasites also belong to the calc-alkaline field, in some Harker diagrams they display different geochemical characteristics than the granitoids (Fig. 9).

Many granulites in the world show low concentration of granitophile elements such as the large ion lithophile elements (LIL) $\mathrm{K}, \mathrm{Rb}, \mathrm{U}, \mathrm{Th}, \mathrm{Cs}$ and high $\mathrm{K} / \mathrm{Rb}$ ratios, perhaps as a result of depletion during granulite facies metamorphism (Rollinson \& Windley 1980, Sighinolfi 1971). The average $\mathrm{K} / \mathrm{Rb}$ ratio of 303 for felsic samples of the Pedra Dourada Charnockite is low in comparison to other granulites. Sighinolfi et al. (1981) found an average $\mathrm{K} / \mathrm{Rb}$ ratio of 625 for a granulite in the state of Bahia (Brazil) and tonalitic granulites from Scourie, Scotland, show a mean $\mathrm{K} / \mathrm{Rb}$ ratio of 1,900 (Rollinson \& Windley, 1980). The Pedra Dourada mean K/Rb ratio of 303 of the charnockite-enderbite and the granitetonalite suites is atypical for depleted rocks and agrees well with the estimates for igneous rocks (Shaw 1968), corroborating a magmatic origin of the studied rocks. Rollinson \& Windley (1980) demonstrate that granulite facies rocks around the world are variably depleted. This geochemical variability is expected if granulite facies rocks are formed by different geological processes. Those of metamorphic origin in the granulite facies accompanied by dehydration reactions and loss of volatiles are likely to be strongly depleted, while 
Table 1 - Representative microprobe analyses (in weight\%) and number of cations per unit formula of minerals of the Pedra Dourada Charnockite.

Tabela 1 - Análises por microssonda representativas (em \% peso) e número de cations por fórmula unitária de minerais do Charnoquito Pedra Dourada.

\begin{tabular}{|c|c|c|c|c|c|c|c|c|c|c|c|c|c|c|c|c|c|}
\hline & \multicolumn{4}{|c|}{$\begin{array}{c}\text { HMI-6E } \\
\text { Enderbite }\end{array}$} & \multicolumn{5}{|c|}{$\begin{array}{c}\text { HMI-9B } \\
\text { Spl*-grt-bt granite }\end{array}$} & \multicolumn{2}{|c|}{$\begin{array}{c}\text { HMI-11C } \\
\text { Grt-bt-granite }\end{array}$} & \multicolumn{6}{|c|}{$\begin{array}{l}\text { HMI-5B } \\
\text { Pyribolite }\end{array}$} \\
\hline & $\mathbf{B t} *$ & Grt & $O p x$ & $\mathbf{P l}$ & Bt & Grt & Pl & Or & Spl & $\mathbf{B t}$ & Grt & Bt & Grt & $\mathbf{C p x}$ & Opx & Amph & PI \\
\hline $\mathrm{SiO}_{2}$ & 36.90 & 37.90 & 50.27 & 59.00 & 37.05 & 38.3 & 63.96 & 65.02 & 0.00 & 36.01 & 37.23 & 35.73 & 37.65 & 52.18 & 50.61 & 41.88 & 55.53 \\
\hline $\mathrm{TiO}_{2}$ & 5.11 & 0.00 & 0.05 & - & 5.40 & 0.00 & - & - & 0.01 & 2.87 & 0.00 & 4.36 & 0.04 & 0.11 & 0.03 & 1.50 & 0.00 \\
\hline $\mathrm{Al}_{2} \mathrm{O}_{3}$ & 14.79 & 21.60 & 2.90 & 25.55 & 15.20 & 21.76 & 23.96 & 19.05 & 52.51 & 17.40 & 21.33 & 14.90 & 21.04 & 1.38 & 0.68 & 11.78 & 28.57 \\
\hline $\mathrm{Cr}_{2} \mathrm{O}_{3}$ & 0.17 & 0.04 & 0.05 & - & 0.27 & 0.08 & - & - & 6.44 & 0.00 & 0.00 & 0.11 & 0.08 & 0.01 & 0.00 & 0.02 & - \\
\hline $\mathrm{Fe}_{2} \mathrm{O}_{3}$ & - & 0.00 & 0.01 & - & - & 0.00 & . & - & 2.12 & - & 0.00 & 0.00 & 0.54 & 2.48 & 0.17 & 0.00 & - \\
\hline $\mathrm{FeO}$ & 14.19 & 29.67 & 25.03 & 0.00 & 14.06 & 30.44 & 0.04 & 0.10 & 18.80 & 16.22 & 31.45 & 18.76 & 26.78 & 8.66 & 30.40 & 17.48 & 0.12 \\
\hline $\mathrm{MgO}$ & 14.16 & 6.89 & 19.39 & - & 13.78 & 7.01 & - & - & 5.73 & 12.29 & 5.86 & 11.66 & 3.30 & 12.12 & 16.15 & 9.52 & - \\
\hline $\mathrm{CaO}$ & 0.00 & 2.36 & 0.15 & 7.58 & 0.00 & 1.57 & 4.84 & 0.04 & - & 0.02 & 1.60 & 0.03 & 8.96 & 23.14 & 0.46 & 11.97 & 11.11 \\
\hline $\mathrm{BaO}$ & - & - & - & 0.00 & - & & 0.02 & 0.68 & - & - & - & 0.00 & 1.60 & - & - & - & 0.04 \\
\hline $\mathrm{MnO}$ & 0.01 & 0.97 & 0.26 & - & 0.01 & 1.27 & - & - & 0.08 & 0.00 & 1.43 & 0.04 & - & 0.24 & 0.71 & 0.08 & - \\
\hline $\mathrm{ZnO}$ & - & - & - & - & - & - & - & - & 13.48 & - & - & 0.00 & - & - & - & - & - \\
\hline $\mathrm{Na}_{2} \mathrm{O}$ & 0.00 & - & 0.00 & 7.26 & 0.06 & - & 9.00 & 1.25 & - & 0.06 & - & 0.03 & - & 0.50 & 0.00 & 1.61 & 5.46 \\
\hline $\mathrm{K}_{2} \mathrm{O}$ & 7.88 & - & - & 0.33 & 7.62 & - & 0.18 & 14.20 & - & 6.60 & - & 8.72 & - & - & - & 1.34 & 0.16 \\
\hline $\mathrm{H}_{2} \mathrm{O}$ & 3.97 & - & - & - & 3.99 & - & - & - & - & 3.90 & - & 3.90 & - & - & - & - & - \\
\hline Total & 97.18 & 99.43 & 98.11 & 99.72 & 97.44 & 100.43 & 102.00 & 100.34 & 99.17 & 95.37 & 98.90 & 98.24 & 99.99 & 100.82 & 99.21 & 99.18 & 100.99 \\
\hline \multicolumn{18}{|l|}{ Cations } \\
\hline $\mathrm{Si}$ & 5.56 & 2.98 & 1.93 & 2.64 & 5.56 & 2.99 & 2.78 & 2.98 & 0.00 & 5.53 & 2.98 & 5.50 & 2.98 & 1.95 & 1.98 & 6.38 & 2.48 \\
\hline $\mathrm{Ti}$ & 0.58 & 0.00 & 0.00 & - & 0.61 & - & - & - & 0.00 & 0.33 & 0.00 & 0.50 & 0.00 & 0.00 & 0.00 & 0.17 & - \\
\hline Al & 2.63 & 2.00 & 0.13 & 1.35 & 2.69 & 2.00 & 1.22 & 1.03 & 14.43 & 3.14 & 2.01 & 2.70 & 1.96 & 0.06 & 0.03 & 2.11 & 1.50 \\
\hline $\mathrm{Cr}$ & 0.01 & 0.00 & 0.00 & - & 0.03 & 0.00 & - & - & 1.18 & 0.00 & 0.00 & 0.01 & 0.01 & 0.00 & 0.00 & 0.00 & - \\
\hline $\mathrm{Fe}^{3+}$ & 0.00 & 0.00 & 0.00 & - & - & 0.00 & - & - & 0.37 & - & 0.00 & 0.00 & 0.03 & 0.07 & 0.00 & 0.00 & - \\
\hline $\mathrm{Fe}^{2+}$ & 1.79 & 1.95 & 0.80 & 0.00 & 1.76 & 1.99 & 0.00 & 0.00 & 3.67 & 2.08 & 2.10 & 2.41 & 1.78 & 0.27 & 0.99 & 2.23 & 0.00 \\
\hline $\mathrm{Mg}$ & 3.18 & 0.81 & 1.11 & - & 3.08 & 0.32 & - & - & 1.99 & 2.81 & 0.70 & 2.67 & 0.39 & 0.67 & 0.94 & 2.16 & - \\
\hline $\mathrm{Ca}$ & 0.00 & 0.20 & 0.00 & 0.36 & 0.00 & 0.13 & 0.22 & 0.00 & 0.00 & 0.00 & 0.14 & - & 0.76 & 0.92 & 0.01 & 1.95 & 0.53 \\
\hline $\mathrm{Ba}$ & . & - & - & 0.00 & - & - & 0.00 & 0.01 & - & - & - & - & - & - & - & 0.00 & 0.00 \\
\hline $\mathrm{Mn}$ & 0.00 & 0.07 & 0.00 & - & 0.00 & 0.08 & - & - & 0.01 & 0.00 & 0.10 & - & 0.10 & - & 0.02 & 0.01 & - \\
\hline $\mathrm{Zn}$ & - & - & - & - & - & - & - & - & 2.32 & - & - & - & - & - & - & 0.00 & - \\
\hline $\mathrm{Na}$ & 0.00 & - & 0.00 & 0.63 & 0.01 & - & 0.76 & 0.11 & - & 0.01 & - & 0.00 & - & 0.03 & - & 0.47 & 0.47 \\
\hline K & 1.51 & - & 0.00 & 0.01 & 1.46 & - & 0.01 & 0.83 & - & 1.29 & - & 1.70 & - & - & - & 0.26 & 0.00 \\
\hline 0 & $\begin{array}{c}24 \\
(\mathrm{O} . \mathrm{OH})\end{array}$ & 12 & 6 & 8 & $\begin{array}{c}24 \\
(\mathrm{O} .0 \mathrm{H})\end{array}$ & 12 & 8 & 8 & 32 & $\begin{array}{c}24 \\
(\mathrm{O} . \mathrm{OH})\end{array}$ & 12 & $\begin{array}{c}24 \\
(\mathrm{O} . \mathrm{OH})\end{array}$ & 12 & 6 & 6 & $\begin{array}{c}24 \\
(\mathrm{O} . \mathrm{OH})\end{array}$ & 8 \\
\hline line & ymbo & ter $\mathbf{F}$ & (19 & 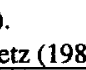 & & & & & & & & & & & & & \\
\hline
\end{tabular}

granulite facies rocks crystallized from dry magmas (as in the Pedra Dourada) tend to be undepleted. Therefore, $\mathrm{K} / \mathrm{Rb}$ ratios might be very helpful to distinguish between igneous and metamorphic rocks.

The majority of the Pedra Dourada felsic rocks fall within the VAG (volcanic arc granitoids) field of the tectonic discrimination diagram of Pearce et al. (1984) shown in Fig. 8. Using the tectonic discrimination scheme for granitoids of Maniar \& Piccoli (1989), the studied rocks could be either continental/island arc granitoids $(\mathrm{CAG} / \mathrm{IAG})$ or continental collison granitoids (CCG). Although the Maniar \& Piccoli-s scheme does not allow and unequivocal distinction between these two granitoid types, in their QAP diagram the studied rocks plot within the $\mathrm{CAG} / \mathrm{IAG}$ field. Island arc granitoids in the studied region are discussed by Cunningham et al. (in preparation), who proposed a six stage model to explain the tectonic evolution of the Costeiro Mobile Belt. According to the authors, the early stages of the evolution of the region studied in this paper were characterized by an active island arc adjoining a subduction complex of Transamazonian age (2.2 
Table 3 - Chemical analyses of selected samples of the Pedra Dourada Charnockite (oxides in weight \%, trace elements in ppm). Tabela 3 - Análises químicas de amostras selecionadas do Charnoquito Pedra Dourada (óxidos em \% peso, elementos traços em ppm).

\begin{tabular}{|c|c|c|c|c|c|c|c|c|c|c|c|c|c|c|}
\hline \multicolumn{6}{|c|}{ Mafic rocks (pyribolites) } & \multicolumn{2}{|c|}{$\begin{array}{l}\text { Mesocratic rocks } \\
\text { (pyriclasites) }\end{array}$} & \multicolumn{7}{|c|}{ Felsic rocks (charnockite-enderbite and granite-tonalite suites) } \\
\hline Sample & 1B & 9D & $11 \mathrm{~A}$ & 5B & 11D & 3B & 3A & $5 \mathbf{A}$ & $11 E$ & $12 \mathrm{~F}$ & $6 \mathrm{C}$ & 4A & 15B & $6 E$ \\
\hline $\mathrm{SiO}_{2}$ & 46.76 & 49.32 & 50.92 & 51.11 & 51.44 & 56.20 & 58.32 & 64.15 & 65.22 & 66.29 & 66.67 & 66.86 & 67.72 & 67.88 \\
\hline $\mathrm{TiO}_{2}$ & 1.32 & 0.77 & 1.49 & 1.45 & 1.56 & 1.11 & 1.40 & 0.66 & 0.47 & 0.40 & 0.73 & 0.51 & 0.58 & 0.62 \\
\hline $\mathrm{Al}_{2} \mathrm{O}_{3}$ & 15.83 & 12.54 & 14.51 & 13.82 & 14.69 & 16.70 & 16.36 & 15.20 & 15.91 & 16.45 & 15.97 & 15.96 & 15.51 & 15.26 \\
\hline $\mathrm{Fe}_{2} \mathrm{O}_{3}$ & 15.62 & 13.35 & 12.70 & 15.30 & 13.75 & 8.47 & 8.86 & 5.60 & 4.12 & 4.36 & 4.91 & 4.56 & 3.85 & 4.80 \\
\hline $\mathrm{MnO}$ & 0.24 & 0.24 & 0.20 & 0.25 & $\cdot 0.21$ & 0.14 & 0.12 & 0.07 & 0.05 & 0.05 & 0.08 & 0.09 & 0.05 & 0.06 \\
\hline $\mathrm{MgO}$ & 6.95 & 8.57 & 6.96 & 5.80 & 6.46 & 4.15 & 3.70 & 3.60 & 1.55 & 2.34 & 1.38 & 1.95 & 1.21 & 2.43 \\
\hline $\mathrm{CaO}$ & 11.62 & 11.44 & 9.34 & 9.57 & 8.00 & 7.08 & 6.48 & 2.93 & 5.12 & 2.13 & 3.59 & 4.01 & 3.37 & 4.20 \\
\hline $\mathrm{Na}_{2} \mathrm{O}$ & 1.15 & 2.49 & 2.36 & 2.78 & 2.25 & 3.20 & 3.02 & 3.40 & 3.60 & 4.88 & 3.55 & 3.10 & 2.93 & 3.47 \\
\hline $\mathrm{K}_{2} \mathrm{O}$ & 0.43 & 0.93 & 0.91 & 0.35 & 1.27 & 1.63 & 1.79 & 2.94 & 2.13 & 2.16 & 2.61 & 2.56 & 3.86 & 1.02 \\
\hline $\mathrm{P}_{2} \mathrm{O}_{5}$ & 0.11 & 0.07 & 0.17 & 0.13 & 0.17 & 0.26 & 0.29 & 0.13 & 1.18 & 0.05 & 0.21 & 0.13 & 0.18 & 0.28 \\
\hline Total & 100.03 & 99.72 & 99.56 & 100.56 & 99.8 & 98.94 & 100.34 & 98.68 & 99.35 & 99.11 & 99.7 & 99.73 & 99.26 & 100.02 \\
\hline $\mathrm{Cr}$ & 233 & 465 & 237 & 116 & 203 & 89 & 74 & 52 & 26 & 115 & 20 & 45 & 20 & 56 \\
\hline $\mathrm{Ni}$ & 181 & 213 & 180 & 86 & 130 & 52 & 45 & 48 & 37 & 75 & 15 & 25 & 14 & 56 \\
\hline Co & 57 & 53 & 34 & 22 & 39 & 24 & 26 & 20 & 11 & 27 & 17 & 21 & 23 & 1 \\
\hline Sc & 45 & 37 & 32 & 39 & 39 & 24 & 17 & 11 & 12 & 7 & 16 & 13 & 3 & 8 \\
\hline v & 365 & 261 & 268 & 346 & 302 & 176 & 176 & 73 & 77 & 57 & 60 & 77 & 49 & 72 \\
\hline $\mathrm{Cu}$ & 85 & 4 & 23 & 85 & 25 & 24 & 28 & 5 & 189 & 35 & 9 & 15 & 7 & 2 \\
\hline $\mathrm{Pb}$ & 27 & 24 & 58 & 26 & 14 & 23 & 18 & 46 & 40 & 40 & 26 & 22 & 22 & 29 \\
\hline $\mathrm{Zn}$ & 129 & 127 & 102 & 116 & 128 & 93 & 88 & 70 & 46 & 70 & 64 & 56 & 40 & 52 \\
\hline Mo & 0 & - & 1 & - & 3 & 4 & 2 & 3 & 0 & 4 & 1 & 1 & 2 & 2 \\
\hline As & 36 & 26 & 15 & 26 & 4 & - & - & 12 & 0 & 0 & 12 & 15 & 22 & 19 \\
\hline $\mathrm{Rb}$ & 3 & 12 & 40 & 5 & 95 & 72 & 76 & 133 & 116 & 90 & 70 & 82 & 101 & 20 \\
\hline $\mathrm{Ba}$ & 45 & 52 & 93 & 59 & 100 & 643 & 858 & 799 & 232 & 577 & 2169 & 806 & 1431 & 457 \\
\hline $\mathrm{Sr}$ & 184 & 78 & 121 & 137 & 126 & 488 & 470 & 298 & 120 & 220 & 358 & 320 & 421 & 286 \\
\hline $\mathrm{Ga}$ & 16 & 13 & 14 & 10 & 18 & 19 & 18 & 20 & 24 & 23 & 20 & 21 & 22 & 20 \\
\hline $\mathrm{Nb}$ & 5 & 7 & 9 & 4 & 19 & 12 & 8 & 13 & 19 & 17 & 13 & 8 & 5 & 6 \\
\hline $\mathrm{Zr}$ & 57 & 48 & 103 & 87 & 95 & 157 & 189 & 305 & 64 & 79 & 363 & 138 & 274 & 322 \\
\hline $\mathrm{Y}$ & 29 & 32 & 34 & 33 & 36 & 33 & 20 & 18 & 155 & 10 & 28 & 16 & 6 & 56 \\
\hline Th & - & 4 & 1 & 1 & 7 & 0 & 0 & 78 & 27 & 5 & 15 & 4 & 16 & 37 \\
\hline U & - & 0 & 0 & 3 & 2 & 0 & 0 & 2 & 14 & 0 & 0 & 0 & 0 & 4 \\
\hline $\mathrm{La}$ & 3 & 0 & 18 & 5 & 12 & 31 & 23 & 148 & 44 & 23 & 128 & 36 & 88 & 110 \\
\hline $\mathrm{Ce}$ & 11 & 14 & 16 & 14 & 34 & 50 & 63 & 257 & 133 & 25 & 219 & 74 & 154 & 210 \\
\hline Pr & 2 & 2 & 4 & 3 & 4 & 7 & 6 & 28 & 11 & 3 & 24 & 7 & 17 & 20 \\
\hline $\mathrm{Nd}$ & 7 & 16 & 11 & 10 & 19 & 29 & 32 & 85 & 66 & 3 & 72 & 29 & 47 & 77 \\
\hline $\mathrm{Sm}$ & 4 & 5 & 4 & 6 & 4 & 7 & 6 & 12 & 12 & 2 & 13 & 7 & 10 & 10 \\
\hline $\mathrm{K} / \mathrm{Rb}$ & 1190 & 643 & 189 & 581 & 111 & 188 & 196 & 184 & 152 & 199 & 310 & 259 & 317 & 423 \\
\hline
\end{tabular}

contacts (Fig. 2, 3 and 4), which show that the felsic rocks intruded the mafic rocks, although more transitional contacts, though less common, do occur; (ii.) the magmatic textures of the felsic charnockitic rocks (Fig. 5) contrast with the unequivocally metamorphic textures of the mafic endmembers; (iii.) the predominantly anhydrous mineralogy; (iv.) the lack of homogeneous trends in many variation diagrams (Fig. 9) and the undepleted geochemical character of the felsic rocks.

The intrusive contacts and the magmatic textures clearly indicate that the felsic rocks of the Pedra Dourada Charnockite were formed by crystallization of granitic melts. Some possibilities for the generation of granitic melts are:
- The differentiation by fractional crystallization of mantle derived magmas would explain at least some of the continental margin calc-alkaline granitoids (Hall 1987) and many felsicmafic associations as well. The smooth trends in the variation diagrams are commonly considered as evidence for consanguinity but can be interpreted in light of a variety of petrological processes such as contamination or different degrees of partial melting in the source region (Atherton 1993).

- The partial melting of crustal rocks heated by hot mantle derived mafic magmas. Clemens (1992) states that the main mechanism by which granitic magmas are generated is by fluid-absent, granulite fades metamorphism at temperatures between $850^{\circ} \mathrm{C}$ and $950^{\circ} \mathrm{C}$ involving the decomposition of micas and amphiboles. This process would generate relatively 
Table 3 - (Continued)

Tabela 3- (Continuação)

\begin{tabular}{|c|c|c|c|c|c|c|c|c|c|c|c|c|c|}
\hline \multirow[b]{2}{*}{ Sample } & \multirow[b]{2}{*}{$12 \mathbf{H}$} & \multirow[b]{2}{*}{$\mathbf{8 A}$} & \multirow[b]{2}{*}{$11 \mathrm{~A}$} & \multicolumn{6}{|c|}{ Felsic rocks (charnockite-enderbite and granite-tonalite suites) } & \multirow[b]{2}{*}{ 6D } & \multirow[b]{2}{*}{$\mathbf{1 A}$} & \multirow[b]{2}{*}{$11 \mathrm{C}$} & \multirow[b]{2}{*}{11} \\
\hline & & & & $\mathbf{7 A}$ & $6 \mathbf{F}$ & 9B & $12 \mathrm{G}$ & 12D2 & $12 \mathrm{C}$ & & & & \\
\hline $\mathrm{SiO} 2$ & 69.56 & 70.52 & 70.82 & 72.14 & 72.84 & 73.14 & 73.80 & 74.04 & 74.49 & 75.33 & 75.48 & 76.14 & 76.31 \\
\hline $\mathrm{TiO} 2$ & 0.37 & 0.40 & 0.29 & 0.35 & 0.21 & 0.29 & 0.01 & 0.22 & 0.03 & 0.21 & 0.20 & 0.15 & 0.11 \\
\hline $\mathrm{Al} 2 \mathrm{O} 3$ & 14.40 & 15.71 & 15.33 & 14.73 & 14.51 & 13.59 & 14.60 & 14.13 & 14.47 & 13.21 & 12.62 & 12.27 & 12.52 \\
\hline $\mathrm{Fe} 2 \mathrm{O} 3$ & 3.84 & 2.48 & 2.32 & 2.92 & 1.72 & 4.61 & 1.14 & 1.65 & 0.71 & 1.16 & 1.77 & 2.44 & 1.20 \\
\hline $\mathrm{MnO}$ & 0.06 & 0.04 & 0.04 & 0.04 & 0.05 & 0.15 & 0.04 & 0.03 & 0.02 & 0.02 & 0.05 & 0.09 & 0.02 \\
\hline $\mathrm{MgO}$ & 2.43 & 0.74 & 0.85 & 0.72 & 0.69 & 1.42 & 0.22 & 1.08 & 0.21 & 0.86 & 0.64 & 0.78 & 0.51 \\
\hline $\mathrm{CaO}$ & 2.56 & 2.36 & 2.30 & 1.93 & 2.47 & 1.91 & 1.36 & 1.92 & 1.18 & 2.09 & 0.59 & 0.71 & 0.55 \\
\hline $\mathrm{Na} 2 \mathrm{O}$ & 3.80 & 3.68 & 3.79 & 3.63 & 3.11 & 3.03 & 2.88 & 4.16 & 2.71 & 3.28 & 2.00 & 1.68 & 1.78 \\
\hline $\mathrm{K} 2 \mathrm{O}$ & 1.85 & 3.74 & 3.52 & 2.43 & 3.61 & 1.74 & 5.51 & 2.18 & 6.08 & 2.84 & 5.00 & 5.38 & 6.45 \\
\hline $\mathrm{P} 205$ & 0.03 & 0.12 & 0.05 & 0.06 & 0.04 & 0.02 & 0.04 & 0.04 & 0.04 & 0.05 & 0.03 & 0.03 & 0.03 \\
\hline Total & 98.9 & 99.79 & 99.31 & 98.95 & 99.25 & 99.9 & 99.6 & 99.45 & 99.94 & 99.05 & 98.38 & 99.67 & 99.48 \\
\hline $\mathrm{Cr}$ & 36 & 19 & 10 & 15 & 25 & 153 & 9 & 28 & 13 & 12 & 12 & 9 & 14 \\
\hline $\mathrm{Ni}$ & 30 & 9 & 20 & 16 & 50 & 76 & 8 & 14 & 8 & 23 & 10 & 3 & 5 \\
\hline Co & 5 & 0 & 13 & 17 & 11 & 43 & 13 & 5 & 13 & 1 & 0 & 0 & 5 \\
\hline Sc & 8 & 7 & 9 & 4 & 4 & 18 & 4 & 3 & 5 & 2 & 5 & 9 & 4 \\
\hline $\mathrm{V}$ & 40 & 29 & 17 & 33 & 17 & 85 & 2 & 23 & 0 & 10 & 18 & 5 & 2 \\
\hline $\mathrm{Cu}$ & 0 & 0 & 0 & 45 & 9 & 14 & 0 & 0 & 0 & 0 & 0 & 0 & 0 \\
\hline $\mathrm{Pb}$ & 28 & 35 & 42 & 28 & 35 & 28 & 45 & 33 & 40 & 47 & 54 & 111 & 53 \\
\hline $\mathrm{Zn}$ & 54 & 53 & 42 & 40 & 26 & 38 & 0 & 18 & 0 & 12 & 20 & 12 & 9 \\
\hline Mo & 2 & 1 & 3 & 0 & 0 & 3 & 0 & 2 & 2 & 0 & 3 & 0 & 0 \\
\hline As & 5 & 6 & 16 & 5 & 6 & 2 & 20 & 23 & 0 & 0 & 11 & 9 & 0 \\
\hline $\mathbf{R b}$ & 73 & 65 & 105 & 101 & 88 & 44 & 112 & 70 & 117 & 63 & 160 & 145 & 159 \\
\hline $\mathrm{Ba}$ & 222 & 1966 & 599 & 472 & 711 & 657 & 755 & 488 & 731 & 752 & 926 & 943 & 702 \\
\hline $\mathrm{Sr}$ & 138 & 543 & 285 & 186 & 202 & 171 & 124 & 173 & 114 & 167 & 137 & 109 & 76 \\
\hline $\mathrm{Ga}$ & 22 & 21 & 24 & 25 & 18 & 18 & 23 & 24 & 20 & 16 & 16 & 15 & 17 \\
\hline $\mathrm{Nb}$ & 14.0 & 4.0 & 13.0 & 8.0 & 5.0 & 5.0 & 0.0 & 10.0 & 3.0 & 3.0 & 10.0 & 5.0 & 4.0 \\
\hline $\mathrm{Zr}$ & 249 & 212 & 121 & 194 & 136 & 215 & 37 & 101 & 41 & 269 & 227 & 233 & 139 \\
\hline $\mathbf{Y}$ & 10 & 7 & 11 & 30 & 19 & 45 & 33 & 8 & 20 & 30 & 20 & 85 & 46 \\
\hline Th & 3 & 22 & 14 & 59 & 28 & 5 & 14 & 10 & 16 & 59 & 9 & 49 & 29 \\
\hline $\mathrm{U}$ & 0 & 0 & 2 & 4 & 0 & 3 & 0 & 0 & 2 & 1 & 2 & 1 & 0 \\
\hline $\mathrm{La}$ & 28 & 109 & 38 & 94 & 45 & 6 & 20 & 36 & 41 & 109 & 25 & 79 & 40 \\
\hline $\mathrm{Ce}$ & 45 & 172 & 52 & 167 & 78 & 34 & 40 & 57 & 55 & 172 & 32 & 127 & 70 \\
\hline $\mathrm{Pr}$ & 6 & 20 & 8 & 18 & 10 & 4 & 6 & 7 & 7 & 19 & 5 & 13 & 7 \\
\hline $\mathrm{Nd}$ & 18 & 52 & 24 & 56 & 27 & 10 & 12 & 26 & 21 & 65 & 15 & 40 & 26 \\
\hline $\mathrm{Sm}$ & 4 & 10 & 5 & 10 & 6 & 6 & 3 & 4 & 5 & 11 & 3 & 7 & 6 \\
\hline $\mathrm{K} / \mathbf{R} \mathbf{b}$ & 210 & 478 & 278 & 200 & 341 & 328 & 408 & 259 & 431 & 374 & 259 & 308 & 337 \\
\hline
\end{tabular}

dry magmas crystallizing mostly anhydrous minerals. Atherton (1993) states that the most, if not all, granites are crustally derived.

There are some evidences against an origin of the Pedra Dourada mafic-felsic rock suite by fractional crystallization differentiation of a mantle-derived magma. These evidences are the lack of ultramafics (at least at the present level of erosion), the scarcity of rocks of intermediate composition, the intrusive character of most felsic rocks (it is difficult to explain how the felsic, more evolved and lighter melts could stay in the deeper levels of the magma chamber and then intrude the overlying mafics), and the lack of smooth geochemical trends.
An origin of the granitoids by partial melting of crustal rocks under granulite facies conditions is supported by the occasional transitional contacts and migmatite-like structures, and by the anhydrous high-grade parageneses. The mafic pyribolites may be the restite constituents of the crust. This is consistent with their metamorphic textures and by the chemical trends indicating the lack of consanguinity between granitoids and pyribolites.

The interpretation of field, textural and geochemical data led to the conclusion that the mafic pyribolites and pyriclasites of the Pedra Dourada Charnockite are likely to be crustal restites. Partial melting under dry conditions of the granulite facies extracted a granitic magma which crystallized as or- 

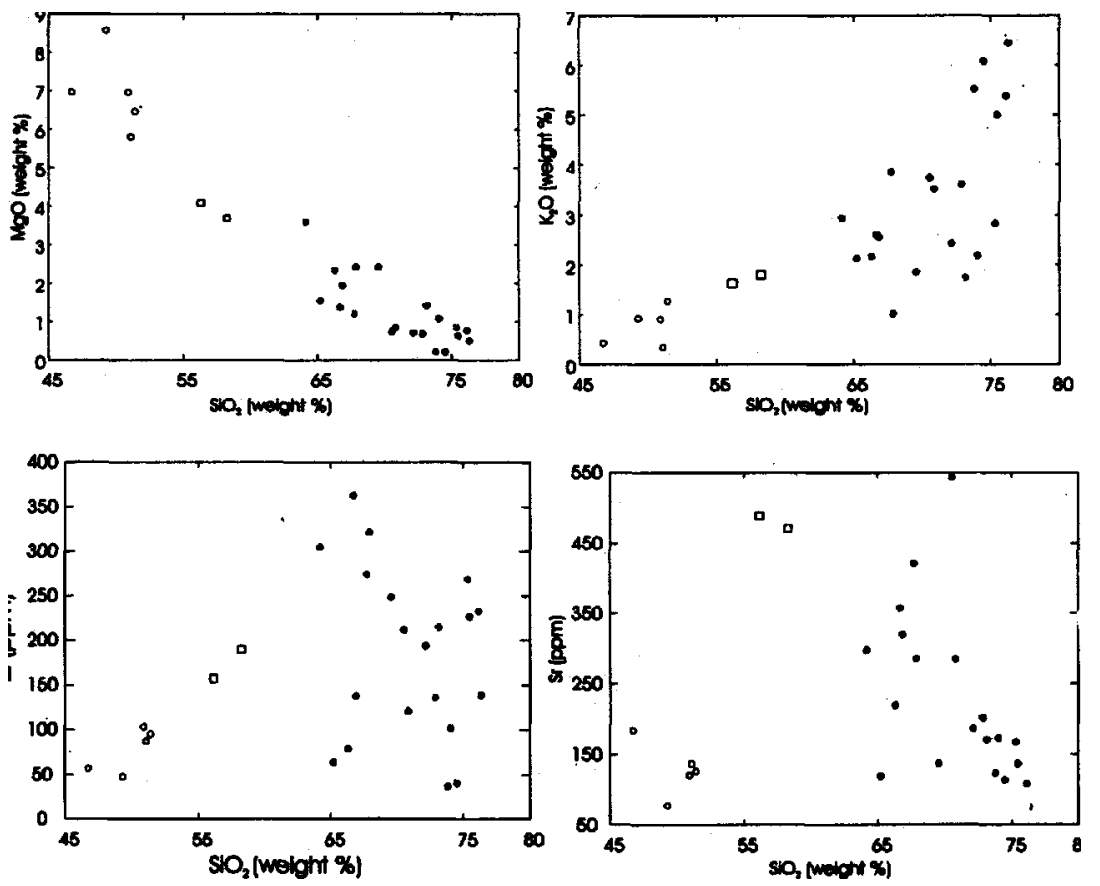

Figure 9 - Selected Marker diagrams for thefelsic and the mafic rocks of the Pedra Dourada Charnockite. Symbols: filled circles = felsic rocks of the charnockite-enderbite and the granite-tonalite series; open circles = mafic rocks (pyribolites); squares = mesocratic rocks (pyriclasites).

Figura 9 - Diagramas selecionados do tipo Marker para as rochas máficas e félsicas do Charnoquito Pedra Dourada. Símbolos: círculos cheios = rochas félsicas das séries charnoquito-enderbito e granito-tonalito; círculos vazios = rochas máficas (piribolitos); quadrados = rochas mesocráticas (piriclasitos).

thopyroxene-bearing charnockitic rocks and biotite-bearing granitic rocks.

Penetrative solid state deformation and recrystallization partially overprinted magmatic features such as the intrusive contacts and the idiomorphic feldspars. The relatively low temperatures obtained by thermometric calculations may result from the re-equilibration of the mineral compositions during deformation.

The results of this study show that charnockites of primary igneous origin may be much more common in the Charnocki- tic Complex of the Costeiro Mobile Belt (Fig. 1), and possibly in other terranes around the world, than assumed so far.

AcknowlegmentS The author gratefully acknowlegdes the financial support from $\mathrm{CNPq}$ (process No. 30.2742/88.3) and CPq/DEGEO/UFOP. Special thanks to Dr. $\mathrm{S}$. Hoernes (University of Bonn, Germany) for the chemical analyses, to Dr. J. C. Gaspar (University of Brasilia, Brazil) for the microprobe analyses, and to Dr. M. A. Carneiro (DEGEO/UFOP) and an anonymous referee for critical review.

\section{REFERENCES}

ALMEIDA, F. F. M. 1977.0 cráton do São Francisco. Rev. Bras. Geoc. 7(4): 349-364.

ALMEIDA, F. F. M.; HASUI, Y.; NEVES, B. B. DE B. \& FUCK, R. A. 1981. Brazilian structural provinces: an introduction. Earth-Sci. Rev. 17(1/2): 1-29.

ASHWAL, L. D.; MORGAN, P. \& HOISCH, D. 1992. Tectonics and heat sources for granulite metamorphism of supracrustal-bearing terranes. Precamb. Res. 55: 525-538.

ATHERTON.M. P. 1993. Granitemagmatism./. Geol. Soc. 150:1009-Í023.

BOHLEN, S. R. 1991. On the formation of granulites. J. Met. Geol. 9: 223-230.

CLEMENS, J. D., 1992. Partial melting and granulite genesis: a partisan overview. Precamb. Res. 55: 297-301.

COORAY, P. G. 1969. Charnockites as metamorphic rocks. Am. J. Sci.. 267: 969-982.

CUNNINGHAM, D. W.; MARSHAK S. \& ALKMIM, F. F. 1997. Proterozoic-present tectonism in the Ribeira Belt, along the Eastern margin of the São Francisco Craton, Brazilian Highlands: the mid- to lower-crustal roots of a polyphase orogen. In preparation.
DE WAARD, D. 1969. The occurence of charnockite in the Adirondacks: a note on the origin and definition of charnockite. Am. J. Set.. 267: 983-987.

FERRY, J. M. \& SPEAR, F. S. 1978. Experimental calibration of the partitioning of $\mathrm{Fe}$ and $\mathrm{Mg}$ between biotite and garnet. Contrib. Mineral. Petrol. 66: 113-117.

FIORENTINI, E. HOERNES, S.; HOFFBAUER, R. \& VITANAGE, P. W. 1990. Nature and scale of fluid-rock exchange in granulite grade rocks of Sri Lanka: a stable isotope study. In: Granulites and crustal evolution (edited by D. Vielzeuf and P. H. Vidal), p. 311-338. Kluwe Academic Publishers, Netherlands.

GRAHAM, C. M.\& POWELL, R. 1984. A garnet-hornblende geothermometer: calibration, testing, and application to the Pelona Schist, southern California. J. Met. Geol. 2: 13-31.

HALL, A. 1987. Igneous Petrology. New York, Longman Scientific \& Technical. $573 \mathrm{p}$

HARLEY, S. L. 1984. An experimental study of the partitioning of Fe and $\mathrm{Mg}$ between garnet and orthopyroxene. Contrib. Mineral. Petrol. 86: 359-373. 
HASUI, Y. \& OLIVEIRA, M. A. F. 1984. Província Mantiqueira. In: $O$ Pré-Cambriono do Brasil (edited by F. F. M. de Almeida and Y. Hasui), p. 308-344. Edgar Blucher, São Paulo, SP, Brazil, 378 p.

HERBERT, H. J.; MULLER, G.; ROESER, H.; SCHULZ-KUHNT, D. \& TOBSCHALL, H. J. 1991. Comparison of geochemical data from gneiss-migmatite and granulite facies terrains, eastern Minas Gerais, Brazil. Chemie derErde 51: 187-200.

HODGES, K. V. \& SPEAR, F. S. 1982. Geothermometry, geobarometry and the AhSiOs triple point at Mt. Moosilauke, New Hampshire. Am. Mineral. 67: 1118-1134.

HOLLAND, T. H. 1900. The charnockite series, a group of Archean hypersthenic rocks in peninsular India. Geol. Surv. India Mem. 28(2): 192-249.

IRVINE, T. N. \& BARAGAR, W. R. A. 1971. A guide to the chemical classification of the common volcanic rocks. Can. J. Earth Sci. 8: 523-548.

JORDT-EVANGELISTA, H. 1992. O grupo Dom Silvério, SE de Minas Gerais: petrografia, metamorfismo, geoquimica'e geologia econômica. REM: Rev. Esc. Minas 45: 140-142.

JORDT-EVANGELISTA, H. \& MULLER, G. 1986. Petrology of atransition zone between the Archean craton and the Coast Belt, SE of the Iron Quadrangle, Brazil. Chemie der Erde 45: 129-145.

KRETZ, R. 1983. Symbols for rock-forming minerals. Am. Mineral. 68: 277-279.

MANIAR, P. D. \& PICCOLI, P. M. 1989. Tectonic discrimination of granitoids. Geol. Soc. Am.. Bull 101: 635-643.

MASCARENHAS, J. F.; PEDREIRA, A. J; MISI, A.; MOTTA, A. C \& SÁ I. H. S. 1984. Província São Francisco. In: O Pré-Cambriano do Brasil (edited by F. F. M. de Almeida and Y. Hasui), p. 46-122. Edgar Blucher, São Paulo, SP, Brazil, 378 p.

MULLEN, E. D. 1983. MnO/TiO2/P2Os: a minor element discriminant for basaltic rocks of oceanic environments and its implications for petrogenesis. Earth Planet. Sci. Lett. 62: 53-62.

NEWTON, R. C. 1992a. An overview of charnockite. Precamb. Res. 55: 399-405.

NEWTON, R. C. 1992b. Charnockitic alteration: evidence for CÜ2 infiltration in granulite facies metamorphism. /. Met. Geol. 10: 383-400.

NEWTON, R. C.; SMITH, J. V. \& WINDLEY, B. F. 1980. Carbonic metamorphism, granulites and crustal growth. Nature 288: 45-50.

O'CONNOR, J. T. 1965. A classification for quartz-rich igneous rocks based on feldspar ratios. U. S. Geol. Sur. Prof. Paper 525(B): 79-84.

PEARCE, J. A. \& CANN, J. R. 1973. Tectonic setting of basic volcanic rocks determined using trace element analyses. Earth Planet. Sci. Lett. 19: 290-300.

PEARCE, J. A.; HARRIS, N. B. W. \& TINDLE, A. G. 1984. Trace element discrimination diagrams for the tectonic interpretation of granitic rocks. J. Petrol. 25: 956-983.
PERCHUK, L. L. \& GERYA, T. V. 1992. The fluid regime of metamorphism and the charnockite reaction in granulites: a review. Int. Geol. Rev. 34: $1-58$.

PERCHUK, L. L. \& LAVRENT'EVA, I. V. 1983. Experimental investigation of exchange equilibria in the system cordieritegarnet-biotite. In: Kinetics and Equilibrium in Mineral Reactions (edited by S. K. Saxena) p. 199-239. Springer, New York, USA.

PERKINS, S. J. \& CHIPERA, S. J. 1985. Garnet-orthopyroxene-plagioclasequartz barometry: refinement and application to the English River subprovince and the Minnesota River valley. Contrib. Mineral. Petrol. 89: 69-80.

ROLLINSON, H. R. \& WINDLEY, B. F. 1980. Selective elemental depletion during metamorphism of Archaean granulites, Scourie, NW Scotland. Contrib. Mineral. Petrol. 72: 257-263.

SCHARBERT, H. G. 1963. Zur Nomenklatur der Gesteine in Granulitfazies. Tschermaks Mineral. Petrogr. Mitt .3: 591-598.

SCHULZ-KUHNT, D.; MULLER, G. \& HOEFS, J. 1990. Petrology of highgrade metamorphic terrains in the Abre Campo-Jequeri quadrangle, eastern Minas Gerais, Brazil. Chemie der Erde 50: 225-245.

SEN, S. K. \& BHATTACHARYA, A. 1984. An orthopyroxene-garnet thermometer and its application to the Madras charnockites. Contrib. Mineral. Petrol. 88: 64-71.

SEN, S. K. \& RAY, S. 1971. Hornblende-pyroxene granulites versus pyroxene granulites: a study from the type charnockite ares. $N . J b$. Mineral. Abh. 115(3): 291-314.

SHAW, D. M. 1968. A review of K-Rb fractionation trends by covariance analysis. Geochim. Cosmochim. Acta 32: 573-601.

SHELLEY, D. 1993. Igneous and Metamorphic Rocks under the Microscope. London, Chapman \& Hall. 445p.

SIGHINOLFI, G. P. 1971. Investigations into deep crustal levels: Fractionating effects and geochemical trends relatd to high-grade metamorphism. Geochim. Cosmochim. Acta 35: 1005-1021.

SIGHINOLFI, G. P.; FIGUEREDO, M. C. H.; FYFE, W. S.; KRONBERG, B. I. \& TANNER OLIVEIRA, M. A. F. 1981. Geochemistry and petrology of the Jequié granulitic complex (Brazil): an Archean basement complex. Contrib. Mineral. Petrol. 78: 263-271.

SPEAR, F. S. 1992. Thermobarometry and P-T paths from granulite facies rocks: an introduction. Precamb. Res. 55: 201-207.

TOBI, A. C. 1971 . The nomenclature of the charnockitic rock suite. $N . J b$. Mineral. Monatshefte 13: 193-205.

WHALEN, J. B.; CURRIE, K. L. \& CHAPPELL, B. W. 1987. A-type granites: geochemical characteristics, discrimination and petrogenesis. Contrib. Mineral. Petrol. 95: 407-419.

\section{MANUSCRITO A898 Recebidfo em 02 de dezembro de 1996 Revisão do autor em 19 de fevereiro de 1997 Revisão aceita em 20 de fevereiro de 1997}

